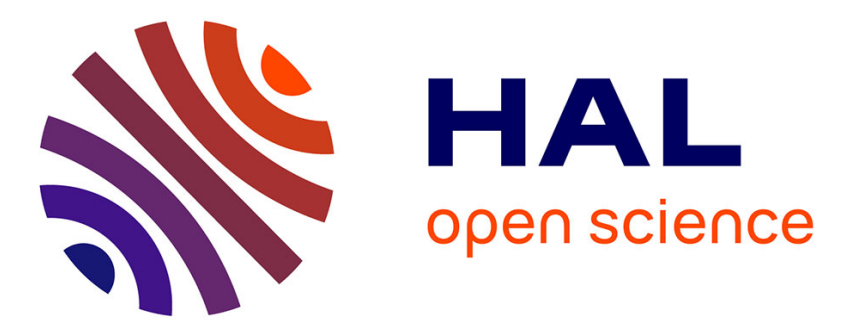

\title{
Pituitary as a target organ for toxic effects of P450 A1 inducing chemicals
}

\author{
T. Andersson, L. Forlin, S. Olsen, Alexis Fostier, Bernard Breton
}

\section{To cite this version:}

T. Andersson, L. Forlin, S. Olsen, Alexis Fostier, Bernard Breton. Pituitary as a target organ for toxic effects of P450 A1 inducing chemicals. Molecular and Cellular Endocrinology, 1993, 91, pp.99-105. 10.1016/0303-7207(93)90260-Q . hal-02713711

\section{HAL Id: hal-02713711 \\ https://hal.inrae.fr/hal-02713711}

Submitted on 1 Jun 2020

HAL is a multi-disciplinary open access archive for the deposit and dissemination of scientific research documents, whether they are published or not. The documents may come from teaching and research institutions in France or abroad, or from public or private research centers.
L'archive ouverte pluridisciplinaire HAL, est destinée au dépôt et à la diffusion de documents scientifiques de niveau recherche, publiés ou non, émanant des établissements d'enseignement et de recherche français ou étrangers, des laboratoires publics ou privés. 


\title{
Pituitary as a target organ for toxic effects of $P 4501$ A1 inducing chemicals
}

\author{
T. Andersson ${ }^{\mathrm{a}}$, L. Förlin ${ }^{\mathrm{a}}, \mathrm{S}$. Olsen ${ }^{\mathrm{b}}$, A. Fostier ${ }^{\mathrm{c}}$ and B. Breton ${ }^{\mathrm{c}}$ \\ a Department of Zoophysiology, University of Göteborg, S-41390 Göteborg, Sweden, \\ ${ }^{h}$ Laboratory of Marine Molecular Biology, University of Bergen, N-5020 Bergen, Norway, and ' INRA, Laboratoire de Physiologie des Poissons, \\ 35042 Rennes Cedex, France
}

(Received 29 July 1992; accepted 16 October 1992)

Key words: Cytochrome P4501A1; $\beta$-Naphthoflavone; Pituitary

\section{Summary}

We report here that cytochrome $P 4501 \mathrm{Al}$ in the male rainbow trout pituitary is highly inducible by $\beta$-naphthoflavone. Pituitary cells containing inducible P4501A1 were identified by double immunostaining as gonadotrophs containing gonadotropin II. Thus, the pituitary gonadotrophs may be target cells for polyaromatic hydrocarbons. Elevated plasma levels of gonadotropin II (GTH II) and testosterone in the induced fish indicated that the functioning of the pituitary was disturbed. Because GTH II regulate the final stage of sexual maturation the results implies that exposure to P4501A1 inducing compounds may disturb this development stage.

\section{Introduction}

Chlorinated dioxins, biphenyls and related aromatic hydrocarbons interfere with several important physiological functions including reproduction (Poland and Knutson, 1982; Safe, 1984). Such interference is probably due to toxin-induced disturbances to the hormonal systems regulating reproduction. This contention is supported by reports of major hormone imbalances, pathological alterations in reproductive organs, and depression of steroid biosynthesis in rodents exposed to this group of chemicals (Silberberg and Mattison, 1987). In nature, at high trophic levels predators are exposed to high concentrations of persistent aromatic hydrocarbons bioaccumulated in the food chain. The low reproductive rates reported for Baltic seals and salmon as well as birds from the Great Lakes have been tentatively attributed to the contamination of the aquatic environment by dioxins, polychlorinated biphenyls (PCB) and structurally related chemicals (Bergman and Olsson, 1985; Mac et al., 1985; Fox et al., 1992). In some of these animal populations, fertility has been completely abolished.

It has been suggested that the various toxic re-

Correspondence to: Tommy Andersson, Department of Zoophysiology, University of Göteborg, Medicinaregatan 18, S-413 90 Göteborg, Sweden. Tel. 46-31 85 36 88; Fax 46-31 853807. sponses induced by dioxins and related chemicals are mediated by a common initial event, i.e., the binding of hydrocarbons to the cytosolic Ah receptor (Landers and Bunce, 1991). The ligand-receptor complex is translocated to the nucleus where it stimulates gene transcription. The role of this receptor in inducing cytochrome P4501A1 ( $P 4501 \mathrm{~A} 1)$ is well understood. The large diversity of toxic effects produced by $2,3,7,8$ tetrachlorodibenzo- $p$-dioxin (TCDD) and related compounds may be due to the fact that the ligand-Ah receptor complex regulates different sets of genes in each cell type.

To determine whether the pituitary would be a target organ for dioxins and dioxin-like compounds, we examined the inducibility of $P 450$-dependent ethoxyresorufin- $O$-deethylase and the localization of $P 4501 \mathrm{~A} 1$ in the tissue. The results show that $P 4501 \mathrm{~A} 1$ is induced specifically in gonadotropin II (GTH II) containing cells. Furthermore, increased plasma levels of GTH II and testosterone were measured in trout treated with P4501A1 inducing compounds.

\section{Materials and methods}

Male rainbow trout in their second reproductive cycle and ranging in weight between $1-2 \mathrm{~kg}$, were obtained from a local fish farm. The fish were acclimated to laboratory conditions for 2 weeks prior weekly i.p. injections of $\beta$-naphthoflavone (BNF) $(5 \mathrm{mg} / \mathrm{kg})$ 
for 10 weeks. Samples were collected when the trout were spermiating. We chose to use BNF as our model inducing compound since this chemical is metabolized faster and is less toxic than TCDD, but both compounds induce the $P 4501 \mathrm{~A} 1$ system through the same receptor mechanism (Boobis et al., 1977).

At sampling the whole pituitary was homogenized in $0.1 \mathrm{M}$ phosphate buffer containing $0.2 \mathrm{mM}$ butylated hydroxytoluene, $1 \mathrm{mM}$ dithiothreitol, $0.1 \mathrm{mM}$ EDTA, and $0.1 \mathrm{mM}$ phenylmethylsulfonyl fluoride. Activities were measured immediately in the homogenate as described previously (Andersson et al., 1985).

Immunoblotting was performed after electrophoresis of samples of $7.5 \%$ acrylamide separating slab gels. Transfer of the protein to nitrocellulose sheets was performed in a Min-protean II blotting cell (Bio-Rad) according to manufacturers procedure. Antiserum containing anti-perch $P 4501 \mathrm{~A} 1 \mathrm{IgG}$ (Celander and Förlin, 1991) was used to study crossreacting proteins. Horseradish-peroxidase conjugated goat anti-rabbit IgG (GAR-HRP) was used as secondary antibody. Color development was performed as described by the manufacturers.

To fix tissue sections for immunohistochemical analysis, they were kept immersed in 0.1 Na-cacodylate buffer ( $\mathrm{pH} 7.3)$ containing $0.4 \%(\mathrm{w} / \mathrm{w})$ p-benzoquinone for $4 \mathrm{~h}$ followed by immersion in $0.1 \mathrm{M} \mathrm{Na}$ cacodylate buffer containing 20\% sucrose for $12 \mathrm{~h}$. Cryostat sliccs $(10 \mu \mathrm{m})$ wcre incubated with antiserum containing perch anti-P4501A1 (Celander and Förlin, 1991) (diluted 500 times) in phosphate-buffered saline containing albumin $(4 \%)$ and $\mathrm{Na}$-azide $(2 \%)$ in a moist chamber overnight at room temperature. Swine antirabbit labeled with fluorescein isothiocyanate was used as a secondary antibody for fluorescence microscopy.

Sections were double stained using an indirect immunofluorescence method including an intermediate step in which rabbit anti-IgG activity was blocked by paraformaldehyde vapor treatment (Wang and Larsson, 1985). Sections were first incubated with anti$P 4501 \mathrm{Al}$ serum (diluted 500 times) and the second antibody was fluorescein isothiocyanate (FITC)-labeled sheep anti-rabbit IgG. After treatment with formaldehyde vapor the sections were incubated with anti-GTH II serum, anti-GTH I serum or anti-GH serum diluted 1000 times. The second antibody was tetramethyl rhodamine isothiocyanate (TRITC)-labeled anti-rabbit IgG. Sections were also stained with the primary antibodies in reverse order which gave the same results. Antibody specificities has been characterized by Suzuki et al. (1988) and Kawauchi et al. (1986). Conditions were optimal for the formaldehyde treatment and primary antibody concentrations used. Immersion of sections from induced fish with preimmune serum or sections from uninduced fish with anti-P4501Al gave no staining. The sections were examined in a fluores-

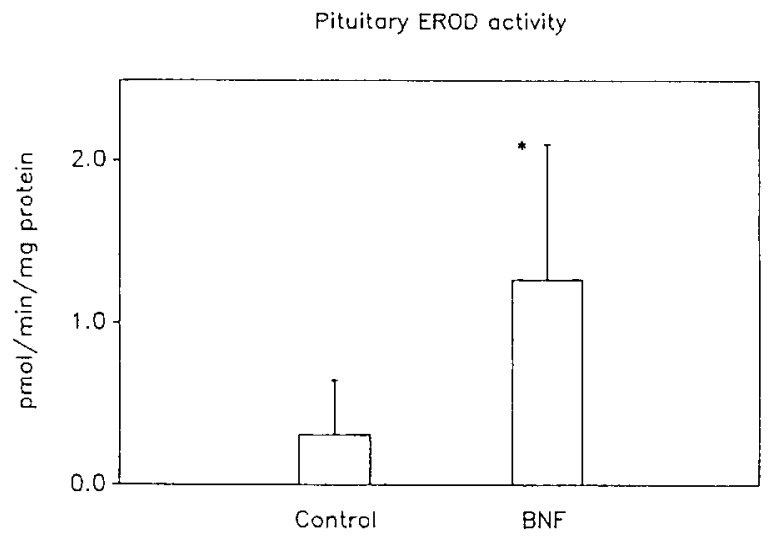

Fig. 1. EROD activity in pituitary homogenate from control and BNF-treated rainbow trout. Values are the mean $\pm S D$ of seven individuals. ${ }^{*}, P<0.05$ compared with control (Mann-Whitney $U$ test).

cence microscope with selective filters at $490 \mathrm{~nm}$ (FITC) and $546 \mathrm{~nm}$ (TRITC).

Plasma levels of GTH II were determined by radioimmunoassay (RIA) as described by Breton et al. (1978), using an antibody developed against the rainbow trout $\mathrm{GTH}_{2}$ and a standard purified from chinook salmon (Oncorhynchus tscawytscha). This gonadotropin was equipotent to Kawauchi's GTH II in RIA as demonstrated by Sumpter and Scott (1989). The testosterone levels were measured by RIA without extraction, as previously described (Fostier and Jalabert, 1986).

\section{Results}

The cytochrome $P 450$ enzyme system in the male rainbow trout (Oncorhynchus mykiss) pituitary was induced about 4-fold by BNF (Fig. 1). Activity was recorded as 7-ethoxyresorufin-O-deethylation (EROD) which is catalyzed by the $P 4501 \mathrm{~A} 1$ isoenzyme in teleosts

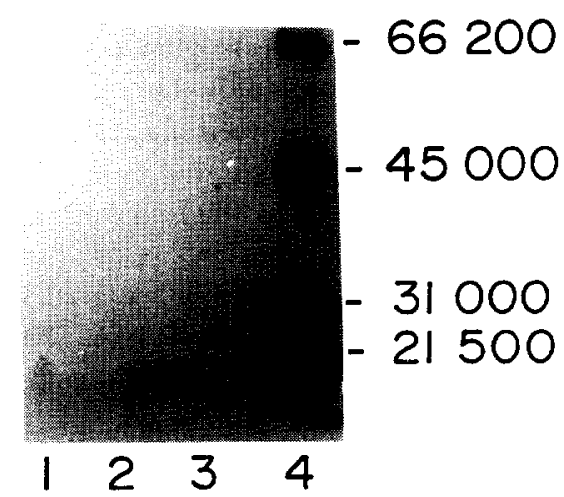

Fig. 2. Western blot analysis of pituitary homogenates from control (C) and BNF-induced male rainbow trout. The lanes contained 10 $\mu \mathrm{g}$ protein of pituitary homogenate from control trout (lane 1), 5 and $10 \mu \mathrm{g}$ protein of pituitary homogenate from BNF treated trout (lanes 2 and 3 , respectively), and molecular weight standards (lane 4). 

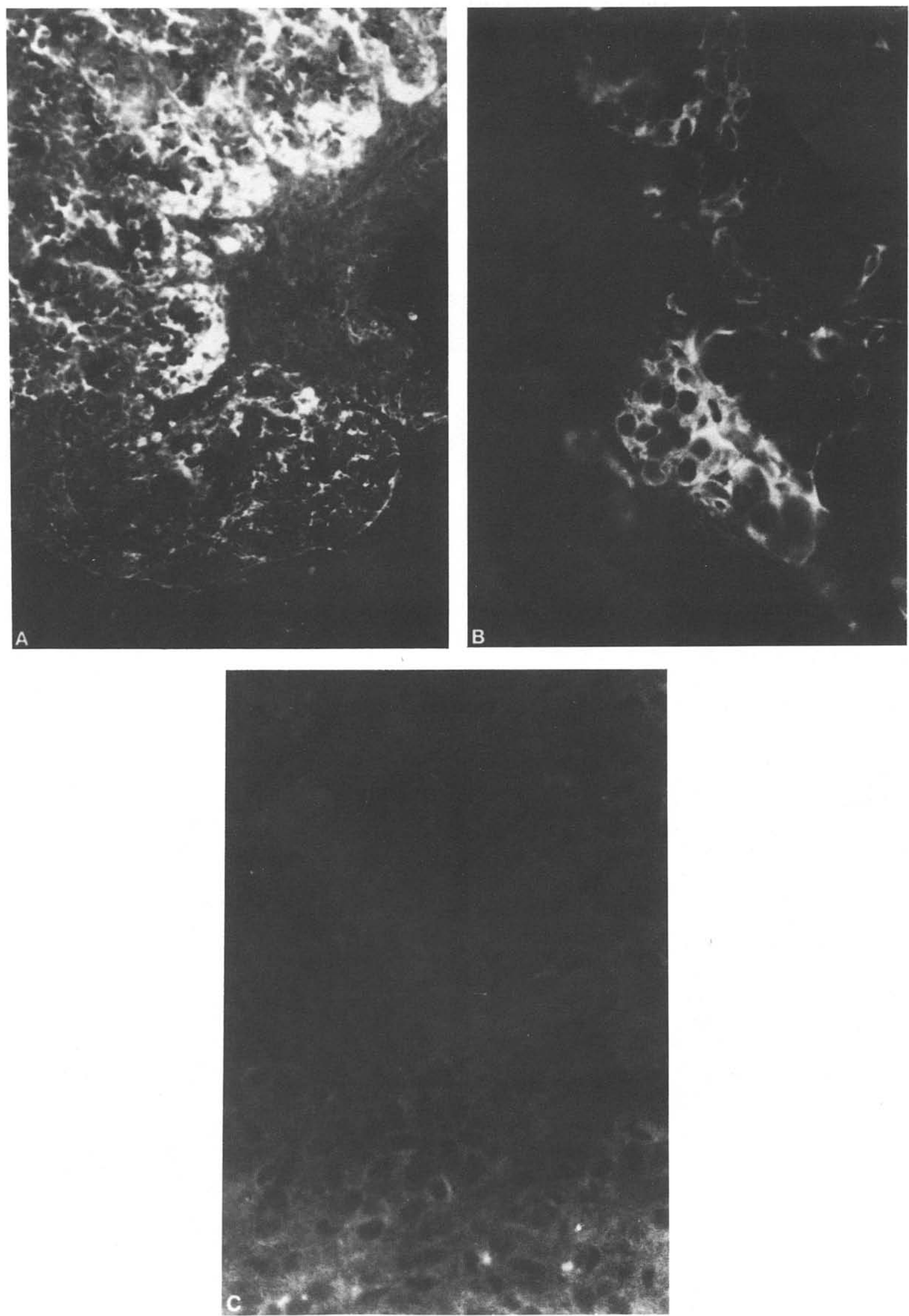

Fig. 3. Immunohistochemical localization of P4501A1 in rainbow trout pituitary slices incubated with a polyclonal antibody diluted 500 times. Distinct staining could be seen in the proximal pars distalis from BNF-treated fish (A and B, magnification $350 \times$ and $2100 \times$, respectively), whereas no staining was seen in untreated fish $(C$, magnification $2100 \times)$. 

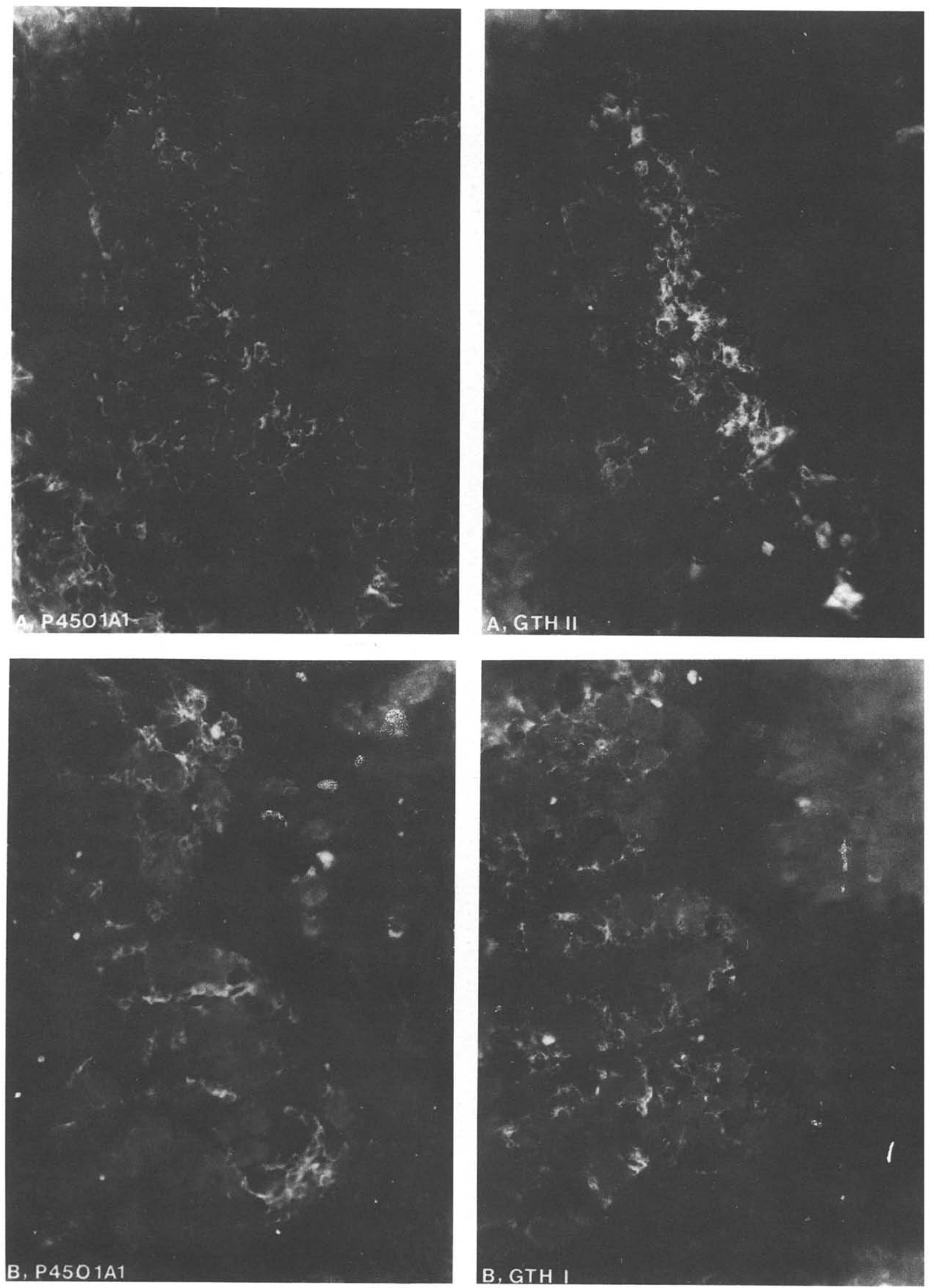

Fig. 4. Fluorescence microscopical double staining of the proximal pars distalis of rainbow trout pituitary slices. Double exposure of the sections using contrasting filters revealed that anti-P4501A1 recngnizes the same cells as anti-GTH II (A1 and A2), whereas no co-localization of $P 4501 \mathrm{~A} 1$ and $\mathrm{GTH} \mathrm{I}(\mathrm{B} 1$ and $\mathrm{B} 2)$ or $P 4501 \mathrm{~A} 1$ and $\mathrm{GH}(\mathrm{C} 1$ and $\mathrm{C} 2)$ could be seen. Magnification is $1250 \times$. 

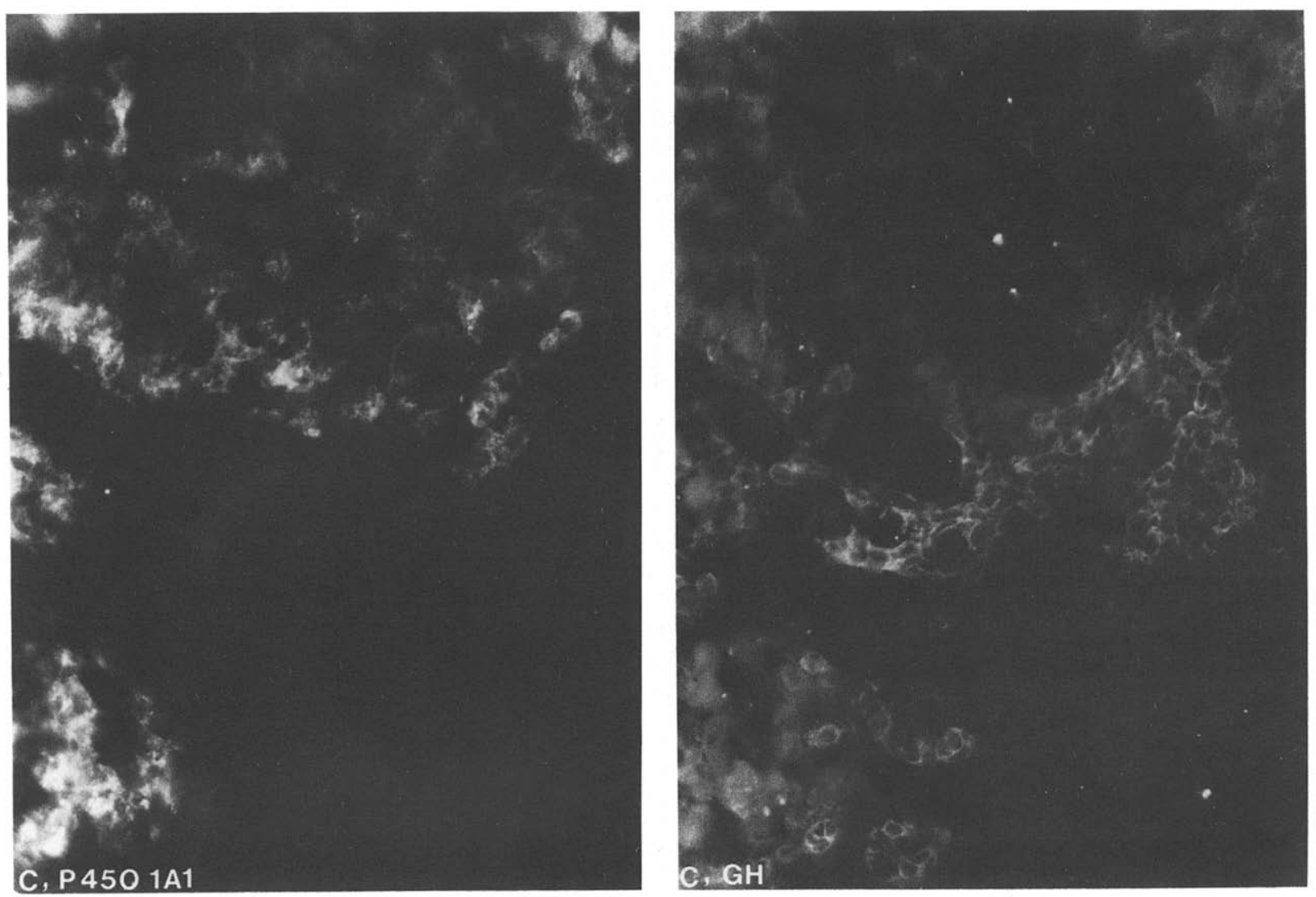

Fig. 4 (continued).

(Stegeman, 1989). Untreated fish contained a low but detectable EROD activity.

Western blot analysis with anti-perch $P 4501 \mathrm{~A} 1$ gave a weak signal at 58,000 in pituitary from BNF treated trout (Fig. 2). No signal was obtained from control trout pituitary homogenates. A molecular mass of 58,000 has previously been reported for hepatic P4501A1 proteins in several teleosts (Goksøyr et al., 1991).

Immunohistochemical examinations of control fish did not reveal any staining after incubation with $P 4501$ A1 antibodies, indicating that the enzyme level

Plasma GTH II level

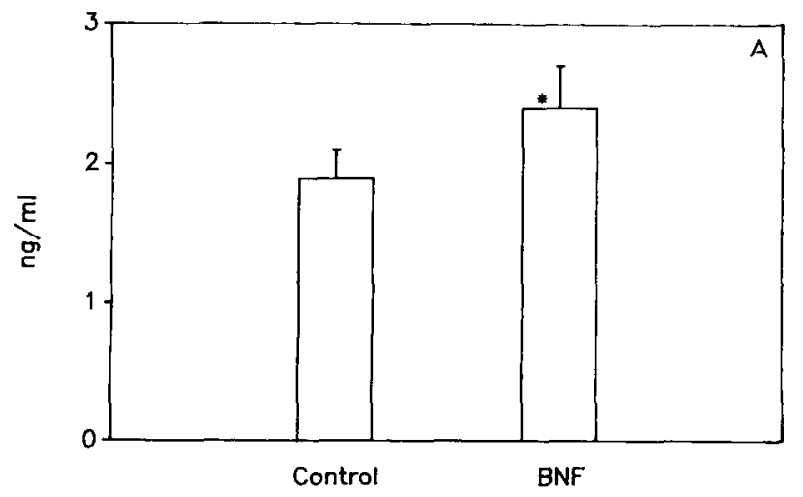

was low. In BNF-treated fish, however, anti-P4501AI clearly stained distinct cells in the proximal pars distalis section of the pituitary (Fig. 3). Double immunostaining revealed that these cells contained gonadotropin II, a peptide hormone in salmonids which is important for the final maturation of the germ cells. The same area also contains GTH I and growth hormone producing cells. However, double immunostaining did not reveal any co-localization of $P 4501 \mathrm{~A} 1$ with the two peptide hormones GTH I and growth hormone.

Plasma levels of GTH II were higher in BNF-ex-

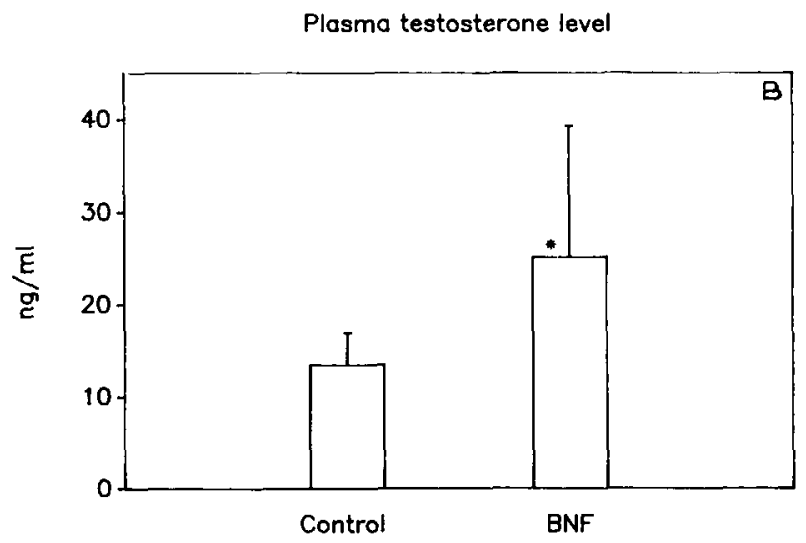

Fig. 5. Plasma levels of GTH II $A$ ) and testosterone $(B)$ in control and BNF-treated rainbow trout. The values \pm SD of 7 individuals. *, $P<0.05$ compared with control (Mann-Whitney $U$ test). 
posed fish than in untreated fish (Fig. 5A). The plasma testosterone level was also increased by BNF treatment ( ig. $5 B$ ), possibly because GTII II stimulates gonadal steroid biosynthesis.

\section{Discussion}

The function and toxicological significance of cytochrome $P 450$ isoenzymes in the pituitary are poorly understood. In mammals the only evidence for the presence of $P 4501 \mathrm{~A} 1$ in the pituitary is that 7-ethoxycoumarin- $O$-deethylase activity is inhibited by polyclonal antibodies raised against the P4501A1 protein in BNF treated rat but not in control rat (Näslund et al., 1988). The present study clearly shows that BNF treatment of male rainbow trout induce the pituitary EROD activity, a P4501A1 catalyzed reaction in teleosts (Stegeman, 1979). Western blot analysis gave further evidence for induction of P4501A1 in the pituitary by BNF. Antibodies against P4501A1 recognized a protein in pituitary from BNF treated trout with the same electrophoretic mobility as hepatic P4501A1 whereas no signal could be detected in control trout. However the signal from pituitary homogenates from BNF treated trout was weak indicating an overall low concentration of the protein. The immunohistochemical analysis showed that inducible P4501Al was confined to certain cells identified with double immunostaining as gonadotrophs containing GTH II. The conlcentration of P4501A1 in the cell population containing the enzyme may therefore be high.

The toxicological and pathological effects of polyaromatic hydrocarbons, including reproductive impairment, are well known. However, their mechanisms of action are not well understood. In male rats TCDD caused a pronounced androgenic deficiency (Moore et al., 1985). The reduction in levels of serum androgens could have been due to TCDD-induced inhibition of the steroidogenic enzymes $17 \alpha$-hydroxylase and 17,20lyase in the testis (Mebus et al., 1987). Recently, Bookstaff et al. (1990) suggested that TCDD alters the negative feed back system by which steroids regulate pituitary hormone secretion by, in some unknown way, increasing the potency of the circulating steroids. In mature male rainbow trout and carp PCB treatment for 4 weeks (weekly injections with $25 \mathrm{mg} / \mathrm{kg}$ body weight) resulted in a $45 \%$ reduction in levels of circulating androgens (probably measuring both 11 ketotestosterone and testosterone) and morphological alterations of the head region of the spermatozoa (Sivarajah et al., 1978a, b). Good correlations between the decreased amount of steroidogenic tissues and plasma steroid levels were seen in Atlantic croaker treated with PCB (Thomas, 1990). In Atlantic croaker PCB also altered the in vitro secretion of gonadotropin from isolated pituitaries. Field investigations on fish living in water polluted with a complex mixture of organic pollutants have also indicated a perturbation in plasma hormone levels which probably caused the observed abnormal reproductive development (Munkittrik et al., 1991; McMaster et al., 1991). In the present study plasma testosterone levels increased by $80 \%$ and GTH II levels by $30 \%$ in response to RNF. These hormonal changes are within the range previously reported to affect reproductive functions in fish (Sivarajah et al., 1978a, b; Thomas, 1990; McMaster et al., 1991; Munkittrik et al., 1991). The study started during the late stage of maturation and sampling was performed after 10 weeks when the fish were spermiating. In spermiating rainbow trout the levels of gonadotropins, measured by a radioimmunoassay preferentially measuring GTH II, in plasma and pituitary reach a plateau whereas the level of androgens rapidly decreases after peak values which are reached before or at the onset of spermiation (Scott and Sumpter, 1989; Sumpter and Scott, 1989). The mechanism for the elevated plasma GTH II and testosterone levels caused by BNF treatment, seen in the present study, is not clear but may be due to a direct effect on the gonadotrophs resulting in an increased secretion of the peptide hormone from the pituitary.

The double immunostaining technique used indicated that trout gonadotrophs containing GTH II were particularly susceptible to induction of P4501Al by BNF. This reflect their capacity to take up aromatic hydrocarbons which can lead to formation of reactive and cytotoxic metabolites formed during $P 450$ catalyzed oxidations of xenobiotics (Gelboin, 1980). Furthermore, other cellular functions involved in gnnadotropin synthesis or release could be affected by $P 4501 \mathrm{Al}$ induction. For example, TCDD exposure has been reported to alter the intracellular $\mathrm{Ca}^{2+}$ homeostasis in heart cells and thymocytes, and it has been suggested that $P 4501 \mathrm{Al}$ participate in the regulation of plasma membrane permeability to $\mathrm{Ca}^{2+}$ (Canga et al., 1988; McConkey et al., 1988; Alvarez et al., 1991). Any effects on $\mathrm{Ca}^{2+}$ regulation in gonadotrophs could directly influence the secretion of the hormone since this ion serves as a second messenger required for hormone release (Conn et al., 1986).

An increase in P4501A1 level could also lead to an elevated metabolism of essential compounds or to the production of metabolites modifying the cascade of intracellular events leading to the release of gonadotropin. In this context, the metabolism of arachidonic acid is of special interest since the metabolic conversion of arachidonic acid seems to be involved in the regulation of hormone release by the pituitary (Fitzpatrick and Murphuy, 1989). Rifkind et al. (1991) showed that TCDD causes a major increase in the NADPH-dependent metabolism of arachidonic acid in chick embryo liver microsomes. Purified rat P4501A1 
was recently shown to be especially active in monohydroxylating arachidonic acid in the 19 position (Falck et al., 1990). Thus the arachidonic acid metabolism in organisms exposed to polyaromatic hydrocarbons may be altered which could result in the impairment of important physiological functions.

In summary, the present study shows that gonadotrophs containing GTH II are target cells for P4501A1 inducing compounds. Elevated plasma levels of GTH II and testosterone suggests that the functioning of the gonadotrophs were disturbed leading to a hormonal imbalance. Because GTH II regulates the final stage of sexual maturation these results implies that exposure to P4501A1 inducers may disturb this development stage.

\section{Acknowledgements}

This study was supported by the Swedish Natural Science Research Council. Professor H. Kawauchi is gratefully acknowledged for supplying GTH I, GTH II and $\mathrm{GH}$ antibodies used in the immunohistochemical part of the study. Dr. A.-C. Jönsson provided helpful advice during the immunohistochemical studies. We are grateful to Eva Nilsson for expert technical assistance and Birgitta Wallander for photographical work.

\section{References}

Alvarez, J., Montero, M. and Garcia-Sancho, J. (1991) Biochem. J. 274, 193-197.

Andersson, T., Pesonen, M. and Johansson, C. (1985) Biochem. Pharmacol. 34, 3309-3314.

Bergman, A. and Olsson, M. (1985) Finnish Game Res. 44, 47-62.

Buobis, A.R., Nebert, D.W. and Felton, J.S. (1977) Molecular Pharmacol. 13, 259-268.

Bookstaff, R.C., Moore, R.W. and Peterson, R.E. (1990) Toxicol. Appl. Pharmacol. 104, 212-224.

Breton, B., Prunet, P. and Reinaud, P. (1978) Ann. Biol. Anim. Biochim. Biophys. 18, 759-765.

Canga, L., Levi, R. and Rifkind, A.B. (1988) Proc. Natl. Acad. Sci. USA $85,905-909$.

Celander, M. and Förlin, L. (1991) Fish Physiol. Biochem. 9, 189-197.

Conn, P.M., Staley, D., Harris, C., Andrews, W.V., Gorospe, W.S., McArdle, C.E., Huckle, W.R. and Hansen, J. (1986) Ann. Rev. Pharmacol. 48, 495-513.
Falck, J.R., Lumin, S., Blair, I., Dishman, E., Martin, M.V., Waxman, D.J., Guengerich, F.P. and Capdevila, J.H. (1990) J. Biol. Chem. 265, 10244-10249.

Fitzpatrick, F.A. and Murphuy, R.C. (1989) Pharmacol. Rev. 40, 229-241.

Fostier, A. and Jalabert, B. (1986) Fish Physiol. Biochem. 2, 87-99.

Fox, G.A., Collins, B., Hayakawa, E., Weselhoh, T.J., Kubiak, T.J. and Erdman, T.C. (1991) J. Great Lake Res. 17, 158-167.

Gelboin, H.V. (1980) Physiol. Rev. 60, 1107-1166.

Goksøyr, A., Andersson, T., Buhler, D.R., Stegeman, J.J., Williams, D.E. and Förlin, L. (1991) Fish Physiol. Biochem. 9, 1-13.

Kawauchi, H., Moriyama, S., Yasuda, A., Yamaguchi, K., Shirahata, K., Kubota, J. and Hirano, T. (1986) Arch. Biochem. Biophys. $244,542-552$.

Landers, J.P. and Bunce, N.J. (1991) Biochem. J. 276, 273-287.

Mac, M.J., Cuntant Edsall, E. and Seelye, J.G. (1985) J. Great Lake Res. 11, 520-529.

McMaster, M.E., Van der Kraak, G.J., Portt, C.B., Munkittrick, K.R., Sibley, P.K., Smith, I.R. and Dixon, D.G. (1991) Aquat. Toxicol. 21, 199-218.

McConkey, D.J., Hartzell, P., Duddy, S.K., Håkansson, H. and Orrenius, S. (1988) Science 242, 256-259.

Mebus, C.A., Reddy, V.R. and Piper, W.N. (1987) Biochem. Pharmacol. 36, 727-731.

Moore, R.W., Potter, C.L., Theobald, H.M., Robinson, J.A. and Peterson, R.E. (1985) Toxicol. Appl. Pharmacol. 79, 99-111.

Mukittrik, K.R., Portt, C.B., Van der Kraak, G.J., Smith, I.R. and Rokosh, D.A. (1991) Can. J. Fish. Aquat. Sci. 48, 1371-1380.

Nä.slund, B.M.A., Glauman, G., Warner, M., Gustafsson, J.-̊. and Hansson, T. (1988) Molecular Pharmacol. 33, 31-37.

Poland, A. and Knutson, J.C. (1982) Ann. Rev. Pharmacol. Toxicol. 22, 517-554.

Rifkind, A.B., Gannon, M. and Gross, S.S. (1990) Biochem. Biophys. Res. Commun. 172, 1180-1188.

Safe, S. (1984) CRC Critical Rev. Toxicol. 13, 319-394.

Scott, A.P. and Sumpter, I.P. (1989) Gen. Comp. Endocrinol. 73, $46-58$.

Silberberg, E.K. and Mattison, D.R. (1987) Am. J. Industrial Med. 11, 131-144.

Sivarajah, K., Franklin, C.S. and Williams, W.P. (1978) J. Fish. Biol. $13,401-409$.

Sivarajah, K., Franklin, C.S. and Williams, W.P. (1978) J. Fish. Biol. $13,411-414$.

Stegeman, J.J. (1989) Xenobiotica 19, 1093-1110.

Sumpter, J.P. and Scott, A.P. (1989) Gen. Comp. Endocrinol. 75, 376-388.

Suzuki, K., Kanamori, A., Nagahama, Y. and Kawauchi, H. (1988) Gen. Comp. Endocrinol. 71, 459-467.

Thomas, P. (1990) J. Exp. Zool. Suppl. 4, 126-128.

Wang, B.-L. and Larsson, L.-I. (1985) Histochem. 83, 47-56. 